\title{
Application of Stability Indicating HPLC Method with UV Detector to the Analysis of Rivaroxaban in Bulk and Tablet Dosage Form
}

\author{
BURLA SUNITHA VENKATA SESHAMAMBA ${ }^{1 *}$, PERURI VEERA VENKATA \\ SATYANARAYANA ${ }^{2}$ and CHANDRA BALA SEKARAN ${ }^{3}$
}

${ }^{1}$ Department of Food Chemistry and Nutrition, College of Food Science and Technology, Bapatla, Andhra Pradesh-522101, India

${ }^{2}$ Department of Biochemistry, Acharya Nagarjuna University, Guntur, Andhra Pradesh-522510, India

${ }^{3}$ Department of Biotechnology, Jagarlamudi Kuppuswamy Choudary College, Guntur, Andhra Pradesh-520010, India

sunithafst@gmail.com

Received 28 May 2014 / Accepted 29 June 2014

\begin{abstract}
A simple and sensitive stability indicating HPLC method is developed for the quantification of rivaroxaban in bulk and tablet dosage form. Chromatographic separation was achieved on an ACE-Ciano column $(250 \mathrm{~mm} \times 4.6 \mathrm{~mm}, 5 \mu \mathrm{m}$ particle size). The mobile phase consists of $0.1 \mathrm{M}$ sodium acetate and methanol $(60: 40 \mathrm{v} / \mathrm{v})$ and was delivered at a flow rate of $1 \mathrm{~mL} / \mathrm{min}$. A UV detector was used for the detection. The rivaroxaban was subjected to stress conditions for the assessment of the stability-indicating nature of the method. The method was validated as per ICH guidelines. The linearity is obtained in the range of $1-120 \mu \mathrm{g} / \mathrm{mL}$. The limit of detection and quantification values is $0.194 \mu \mathrm{g} / \mathrm{mL}$ and $0.648 \mu \mathrm{g} / \mathrm{mL}$ respectively. The intra and inter-day $\%$ RSD values were below $1 \%$. Intra and inter-day accuracies were within $100.10 \%$ and $100.40 \%$, respectively. Degradation products resulting from the stress studies have no interfere with the detection of rivaroxaban. The average recovery of rivaroxaban in tablet dosage form was $99.74 \%$ with $\%$ RSD of $0.421 \%$. The developed method was proved adequate for quantitative determination of rivaroxiban in presence of its degradation products.
\end{abstract}

Keywords: Analysis, HPLC, Rivaroxaban, Stability indicating, Tablets

\section{Introduction}

Rivaroxaban (RXN), (S)-5-Chlor- $N$-\{2-oxo-3-[4-(3-oxomorpholin-4-yl)phenyl]-1,3oxazolidin-5-lmethyl thiophen-2-carbamid, is a novel, oral, direct Factor Xa inhibitor approved for the prevention of venous thromboembolism in adult patients who have undergone hip or knee replacement surgery ${ }^{1,2}$. 
Muralikrishna and $\mathrm{Kasad}^{3}$, Sekaran et $a l^{4}$ Satyanarayana and Madhavi ${ }^{5}$ have determined RXN in formulations using spectrophotometry. Satyanarayana and Madhavi ${ }^{6}$ and Sekhar et al. ${ }^{7}$ have reported RP-HPLC method for the determination of RXN in formulations. Assay of RXN in human plasma by HPLC-MS/MS has been reported by Rohde $^{8}$. Anti-factor Xa chromogenic assay method have been applied for quantification of RXN in human plasma by Mani et al. ${ }^{9}$ Asmis et al. ${ }^{10}$ Samama et al. ${ }^{11}$ and Harenberg et al. ${ }^{12}$ Stability indicating HPLC method is the most preferential technique for the analysis of drugs in the presence of its degradants. Celebier et al. ${ }^{13}$ and Kasad and Muralikrishna ${ }^{14}$ described stability indicating HPLC methods for the quantification of RXN.

The present manuscript describes a sensitive, selective, precise and accurate stability indicating HPLC method for the quantification of RXN in tablet formulations in accordance with ICH guidelines ${ }^{15,16}$.

\section{Experimental}

The chromatographic analysis was performed with Waters Alliance HPLC system equipped with 2695 separation modules having 2996 photodiode array detector. HPLC analysis was conducted in an ACE-Ciano column $(250 \mathrm{~mm} \times 4.6 \mathrm{~mm}, 5 \mu \mathrm{m}$ particle size $)$.

\section{Chemicals}

Solvents and chemicals used were of HPLC and analytical grade, respectively. Pharmaceutical grade RXN was kindly supplied by Rainbow Pharma Training Lab, Hyderabad. Xeralto tablets (Bayer India Limited Mumbai, India) claimed to contain $10 \mathrm{mg}$ of RXN were purchased from the local pharmacy store.

\section{Mobile phase preparation}

The mobile phase is composed of $0.1 \mathrm{M}$ sodium acetate (Merck, Mumbai, India) and methanol (Thermo Fisher Scientific India Pvt. Ltd, Mumbai, India) in the ratio of 60:40 $(v / v)$. The $\mathrm{pH}$ of the mobile phase was adjusted to 5.5 with $85 \%$ orthophosphoric acid (Thermo Fisher Scientific India Pvt. Ltd, Mumbai, India). The mobile phase was degassed and filtered via $0.45 \mu \mathrm{m}$ membrane filter before use.

\section{Stock Standard solution preparation}

A stock standard solution of RXN (1 mg/mL) was prepared in the mobile phase.

\section{Chromatographic conditions}

The HPLC parameters such as run time 6 minutes, $1 \mathrm{~mL} / \mathrm{min}$ as flow rate, injection volume of $10 \mu \mathrm{L}$ and column temperature of $30^{\circ} \mathrm{C}$ were finalized during development. RXN was detected at $247 \mathrm{~nm}$.

\section{General assay procedure}

The stock standard solution $(1 \mathrm{mg} / \mathrm{mL})$ was diluted with mobile phase to obtain working standard solutions in the concentration range of $1-120 \mu \mathrm{g} / \mathrm{mL} \mathrm{RXN}$. Each concentration was injected into the HPLC system thrice. The mean peak area versus corresponding concentrations of RXN was plotted and the calibration curve was drawn. The concentration of the RXN in unknown samples was read from the calibration curve or computed from the regression equation.

\section{Analysis of $R X N$ in tablets}

Twenty tablets were weighed and subsequently powdered. An accurately weighed amount of powder equivalent to $50 \mathrm{mg} \mathrm{RXN}$ was transferred into a $50 \mathrm{~mL}$ volumetric flask and dissolved 
in $20 \mathrm{~mL}$ of mobile phase. This mixture was sonicated for 15 minutes and the resulting solution was then filtered through a $0.45 \mu \mathrm{m}$ membrane filter, followed by the addition of mobile phase to the $50 \mathrm{~mL}$ mark to obtain a stock solution $(1 \mathrm{mg} / \mathrm{mL})$. The stock solution was appropriately diluted with mobile phase to obtain the suitable working concentration $(80$ $\mu \mathrm{g} / \mathrm{mL})$. The working standard solution was injected into the HPLC system thrice. The concentration of the RXN in the tablets was calculated using the calibration curve or from the regression equation.

\section{Analysis of Placebo blank solution}

An accurately weighed amount of starch $(10 \mathrm{mg})$, acacia $(10 \mathrm{mg})$, hydroxyl cellulose (10 $\mathrm{mg})$, sodium citrate $(10 \mathrm{mg})$, talc $(10 \mathrm{mg})$, magnesium stearate $(10 \mathrm{mg})$, lactose $(10 \mathrm{mg})$, glucose $(10 \mathrm{mg})$ and sodium alginate $(10 \mathrm{mg})$ were transferred into a $50 \mathrm{~mL}$ volumetric flask containing $30 \mathrm{~mL}$ of mobile phase. This mixture was sonicated for 15 minutes, filtered and followed by the addition of mobile phase to the $50 \mathrm{~mL}$ mark. This solution was injected into the HPLC system.

\section{Procedure for forced degradation studies} Acid and alkali degradation

In order to perform acid and alkaline degradation, $100 \mathrm{mg}$ of RXN was mixed with $10 \mathrm{~mL}$ of $0.1 \mathrm{~N} \mathrm{HCl}$ and $0.1 \mathrm{~N} \mathrm{NaOH}$ in $100 \mathrm{~mL}$ volumetric flasks, respectively. The solutions were allowed to react for 2 hours at $80^{\circ} \mathrm{C}$ temperature in the water bath. After that, the solutions were neutralized with $0.1 \mathrm{~N} \mathrm{HCl}$ (alkaline degradation), $0.1 \mathrm{~N} \mathrm{NaOH}$ (acid degradation) and then diluted with mobile phase up to the mark.

\section{Oxidative degradation}

To promote the oxidation, $100 \mathrm{mg}$ of $\mathrm{RXN}$ was mixed with $10 \mathrm{~mL}$ of $3 \% \mathrm{H}_{2} \mathrm{O}_{2}$ in $100 \mathrm{~mL}$ volumetric flask and left to react for 2 hours at $80^{\circ} \mathrm{C}$ temperature in the water bath. After oxidation, the solution was diluted with mobile phase up to the mark.

\section{Dry heat degradation}

For this purpose, $100 \mathrm{mg}$ of RXN was taken in glass petri dish and kept in a hot air oven $\left(105^{\circ} \mathrm{C}\right)$ for 2 hours. After the specified time, the sample was transferred to a $100 \mathrm{~mL}$ volumetric flask containing $30 \mathrm{~mL}$ of mobile phase, mixed well and diluted up to the mark with mobile phase.

\section{Photolytic degradation}

For photolytic degradation, $100 \mathrm{mg}$ of RXN was taken in a glass petri dish and exposed to sunlight for $24 \mathrm{~h}$. After the degradation, the sample was transferred to a $100 \mathrm{~mL}$ volumetric flask containing $30 \mathrm{~mL}$ of mobile phase and mixed well. The volume of the flask was completed up to mark with mobile phase.

The above degraded sample solutions were filtered and appropriately diluted with mobile phase to $80 \mu \mathrm{g} / \mathrm{mL}$ of $\mathrm{RXN}$. The degraded sample solutions were injected into the HPLC system. The respective chromatograms and peak area were recorded.

\section{Results and Discussion}

\section{Method development}

During the method development two columns [thermo BDS hypersil-C8 (250 $\mathrm{mm} \times 4.6 \mathrm{~mm} \times 5$ $\mu \mathrm{m})$ and ACE-Ciano column ( $250 \mathrm{~mm} \times 4.6 \mathrm{~mm}, 5 \mu \mathrm{m}$ particle size $)$, different $\mathrm{pH}$ values (3-7) 
and two organic solvents (methanol and acetonitrile) were tested. Acceptable separation, peak shape and symmetry, with a retention time of 4.462 minutes, were achieved with ACE-Ciano column $(250 \mathrm{~mm} \times 4.6 \mathrm{~mm}, 5 \mu \mathrm{m}$ particle size $)$, mobile phase consisting of $0.1 \mathrm{M}$ Sodium acetate (pH 5.5): methanol $(60: 40, v / v)$ at $1 \mathrm{~mL} / \mathrm{min}$ flow rate and $30{ }^{\circ} \mathrm{C}$ temperature. The $\mathrm{RXN}$ solution in mobile phase was scanned by UV-visible spectrophotometer. It was observed that the maximum absorbance of RXN was obtained at $247 \mathrm{~nm}$.

\section{Method validation}

\section{System suitability}

For this purpose, five replicate injections of freshly prepared standard solutions $(80 \mu \mathrm{g} / \mathrm{mL})$ were made. Percentage relative standard deviation of the system suitability parameters was calculated. The low percentage relative standard deviation values (Table 1) indicate that all the system suitability parameters are within the acceptable limits.

Table 1. System suitability

\begin{tabular}{lcc}
\hline Parameter & $\begin{array}{c}\text { Mean value } \\
(\mathrm{n}=5)\end{array}$ & $\%$ RSD \\
\hline Retention Time (min) & 4.469 & 0.136 \\
Peak area & 13376045 & 0.289 \\
Theoretical Plates (n) & 5232 & 1.325 \\
Plates per Meter (N) & 21292 & 1.326 \\
Height equivalent to theoretical & $4.696 \times 10^{5}$ & 1.320 \\
plate (HETP)(mm) & & \\
Tailing factor & 1.259 & 0.258 \\
\hline
\end{tabular}

\section{Linearity}

Linearity was found in the concentration range $1-120 \mu \mathrm{g} / \mathrm{mL} \mathrm{RXN}$. The regression equation was: $\mathrm{A}=167925 x-99.638$ (where $\mathrm{A}=$ peak area, and $x=$ concentration of $\mathrm{RXN}$ in $\mu \mathrm{g} / \mathrm{mL}$ ) with regression coefficient $\left(R^{2}\right)$ of 0.9992 .

\section{Sensitivity ( $L O D$ and $L O Q$ )}

For the determination of LOD and LOQ, five replicate injections of dilute solutions with known concentration $(1 \mu \mathrm{g} / \mathrm{mL})$ were injected into the HPLC system. The LOD and LOQ of the method are found to be $0.194 \mu \mathrm{g} / \mathrm{mL}$ and $0.648 \mu \mathrm{g} / \mathrm{mL}$, respectively. These values indicate the excellent sensitivity of the proposed method.

\section{Precision and Accuracy}

The intra- and inter-day precision and accuracy of the method was carried out at three different concentration levels $(1 \mu \mathrm{g} / \mathrm{mL}, 80 \mu \mathrm{g} / \mathrm{mL}$ and $120 \mu \mathrm{g} / \mathrm{mL})$. The precision and accuracy was expressed in terms of percentage relative standard deviation (\%RSD) and percentage recovery, respectively. The low \%RSD $(<1)$ and good percentage recovery values showed that the precision and accuracy of the method was good (Table 2 ).

\section{Recovery studies via standard addition method}

The accuracy of the proposed method was further assessed by carrying out recovery studies through standard addition method. The preanalyzed tablet samples were spiked with $50 \%$, $100 \%$ and $150 \%$ of RXN found in tablet sample. The percent recovery values (Table 3) indicate that the recovery was good and the excipients present in the tablet dosage form did not interfere in the assay of RXN. 
Table 2. Precision and accuracy

\begin{tabular}{ccccccc}
\hline Type of & \multicolumn{2}{c}{ Concentration of RXN $(\mu \mathrm{g} / \mathrm{mL})$} & Precision & \multicolumn{2}{c}{ Accuracy } \\
\cline { 2 - 3 } \cline { 6 - 7 } analysis & Taken & Found $(\mathrm{n}=5)$ & \%RSD & \% Recovery & \% Error \\
\hline Intra-day & 1 & 1.001 & 0.579 & 100.100 & 0.100 \\
analysis & 80 & 79.946 & 0.268 & 99.932 & 0.068 \\
& 120 & 119.858 & 0.112 & 99.881 & 0.119 \\
\hline Inter-day & 1 & 1.004 & 0.298 & 100.400 & 0.400 \\
analysis & 80 & 79.995 & 0.322 & 99.993 & 0.007 \\
& 120 & 120.145 & 0.064 & 100.120 & 0.120 \\
\hline
\end{tabular}

Table 3. Quantification of RXN by standard addition method

\begin{tabular}{|c|c|c|c|}
\hline \multicolumn{2}{|c|}{ Concentration of RXN, mg } & $\%$ & $\%$ \\
\hline In tablet + Spiked & Found $(\mathrm{n}=3)$ & RSD & Recovery \\
\hline $10+5$ & 14.931 & 0.314 & 99.540 \\
\hline $10+10$ & 19.932 & 0321 & 99.660 \\
\hline $10+15$ & 24.950 & 0.156 & 99.980 \\
\hline
\end{tabular}

\section{Selectivity}

The selectivity of the method was evaluated through the comparison of the chromatograms of placebo blank solution, blank mobile phase and tablet sample solution with the standard drug solution $(80 \mu \mathrm{g} / \mathrm{mL})$. There is no peak interference of mobile phase blank, placebo blank and tablet excipients at the retention time of RXN (Figure 1). The results established the selectivity of the method.
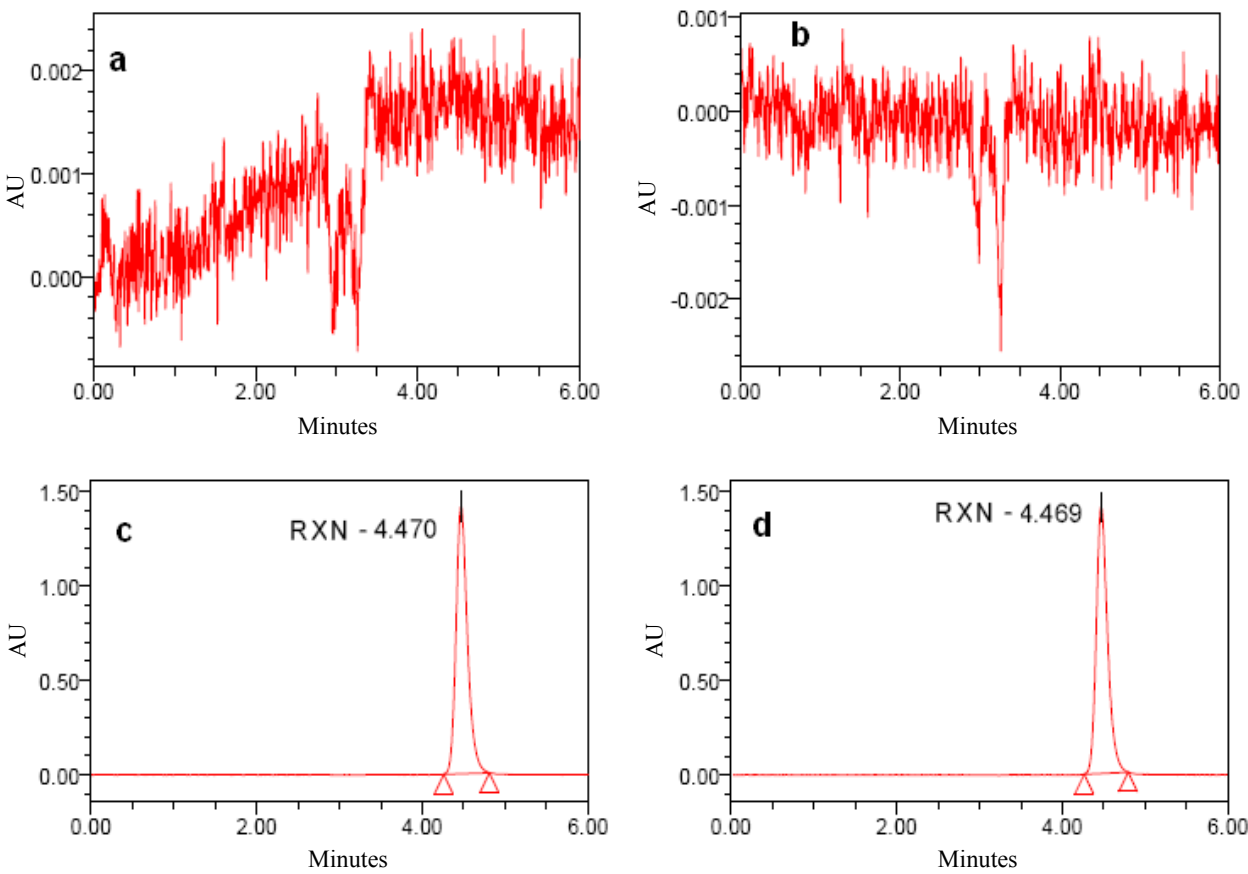

Figure 1. Chromatogram of (a) Mobile phase blank (b) Placebo blank (c) Pure RXN (d) RXN tablet sample 


\section{Specificity}

In order to evaluate the specificity of the proposed method, forced degradation studies were performed. The samples submitted to acid and alkaline conditions, RXN content had a decrease of $7.705 \%$ and $8.851 \%$, respectively. When the oxidation with $\mathrm{H}_{2} \mathrm{O}_{2}$ was promoted, the RXN content had a decrease of $6.559 \%$. When the RXN powder was exposed to dry heat at $105^{\circ} \mathrm{C}$ for 2 hours, $9.186 \%$ of $\mathrm{RXN}$ degradation was observed. $7.304 \%$ of $\mathrm{RXN}$ degradation was observed after exposure of solid drug to sunlight for 24 hours. The chromatograms recorded for the degradation samples revealed no peaks within retention time of RXN (Figure 2). The good resolution of RXN peak and the degradation product in all the situations could be observed, indicating the specificity of the method.
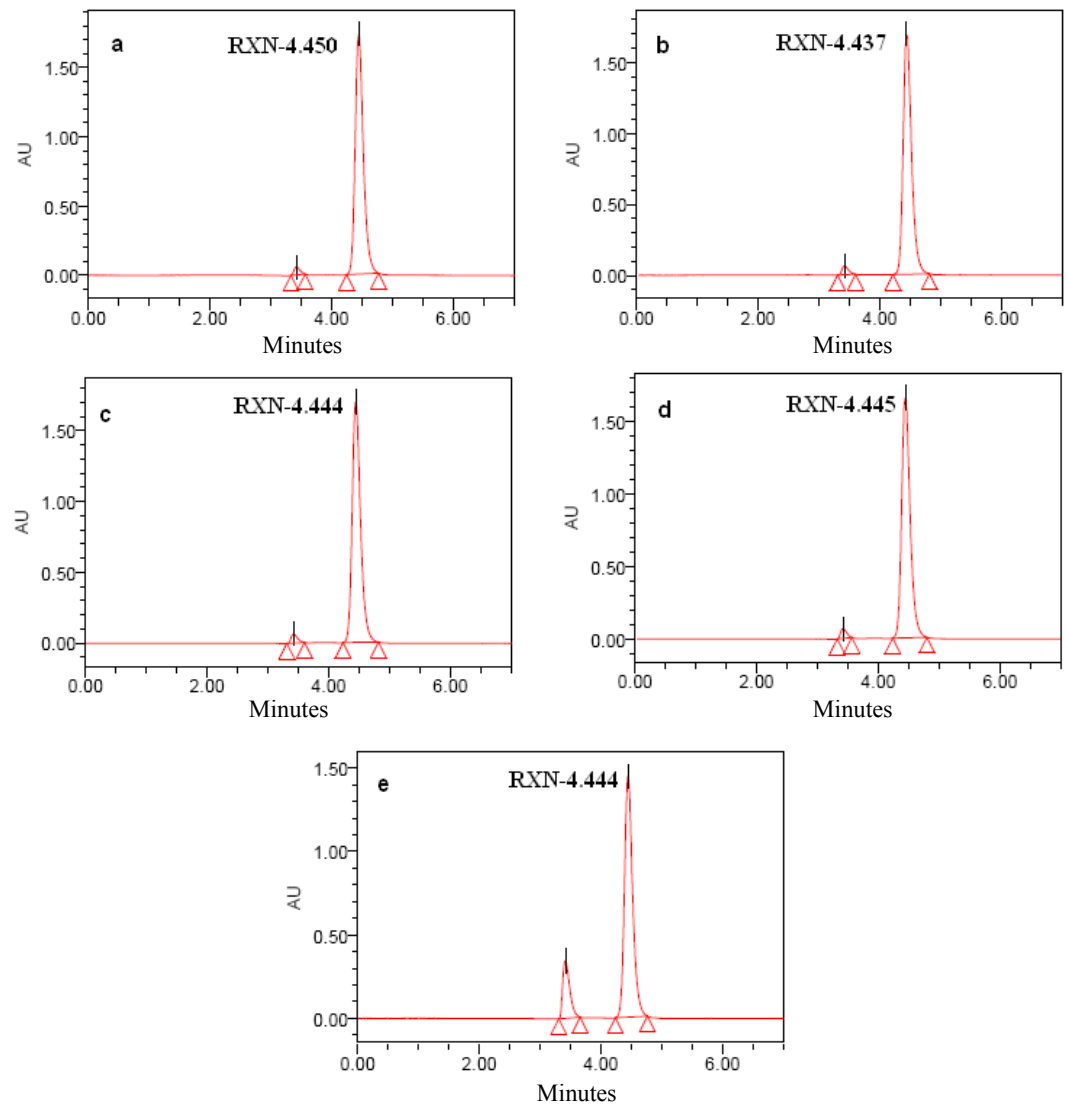

Figure 2. Chromatogram of RXN after (a) Acid degradation (b) Alkali degradation (c) Oxidative degradation (d) Dry heat degradation (e) Photolytic degradation

\section{Robustness}

The robustness of the method was determined by analyzing the RXN under a variety of conditions of the method parameters, such as the mobile phase ratio, $\mathrm{pH}$ of the mobile phase, flow rate and column temperature. The low \%RSD values $(<1)$ (Table 4$)$ indicate that there were no significant changes in the peak area when deliberate modifications were made in the experimental conditions, consequently showing the method to be robust. 
Table 4. Robustness

\begin{tabular}{|c|c|c|c|c|c|}
\hline \multirow{2}{*}{$\begin{array}{c}\text { Experimental } \\
\text { variable }\end{array}$} & \multirow{2}{*}{$\begin{array}{l}\text { Investigated } \\
\text { range }\end{array}$} & \multicolumn{2}{|c|}{$1 \mu \mathrm{g} / \mathrm{mL} \mathrm{RXN}$} & \multicolumn{2}{|c|}{$120 \mu \mathrm{g} / \mathrm{mL}$ RXN } \\
\hline & & $\begin{array}{c}\text { Mean Peak } \\
\text { area }(n=3)\end{array}$ & $\% \mathrm{RSD}$ & $\begin{array}{c}\text { Mean Peak } \\
\text { area }(n=3)\end{array}$ & $\% \mathrm{RSD}$ \\
\hline Mobile phase & $58: 42$ & & & & \\
\hline \multirow[t]{2}{*}{ ratio $^{*}(v / v)$} & $60: 40$ & 166975 & 0.234 & 20017035 & 0.290 \\
\hline & $62: 38$ & & & & \\
\hline $\mathrm{pH}$ of mobile & 5.1 & & & & \\
\hline \multirow[t]{2}{*}{ phase } & 5.2 & 166823 & 0.348 & 20005713 & 0.104 \\
\hline & 5.3 & & & & \\
\hline \multirow{3}{*}{$\begin{array}{l}\text { Temperature of } \\
\text { the column }\left({ }^{\circ} \mathrm{C}\right)\end{array}$} & 28 & & & & \\
\hline & 30 & 165607 & 1.024 & 20037150 & 0.576 \\
\hline & 32 & & & & \\
\hline Flow rate of & 0.9 & & & & \\
\hline mobile phase & 1.0 & 170356 & 0.363 & 20033122 & 0.412 \\
\hline$(\mathrm{mL} / \mathrm{min})$ & 1.1 & & & & \\
\hline
\end{tabular}

\section{Application to tablet dosage forms}

The tablet formulations containing RXN were analyzed using the developed HPLC method. The percent recovery was $99.74 \%$, while the RSD value was $0.421 \%$. The recovery value indicates the non interference of commonly added tablet excipients with the assay.

\section{Comparison of the proposed method with the reported methods}

In comparison with the earlier reported methods for the quantification of RXN (Table 5), the proposed method has the advantages such as broad linearity range ${ }^{6-9,16}$, more precise $\mathrm{e}^{3-6,13,14}$, more accurate $e^{3-6,8,11,13,14}$ and sensitive ${ }^{5-7}$. Unlike the bioanalytical methods ${ }^{8-12}$, the proposed method does not require cumbersome extraction procedure, internal standard, costly detector system and expertise operational personnel. The reported RP-HPLC and stability indicating HPLC methods used acetonitrile in their mobile phase which probably will raise the cost of the method. In all the reported methods, except the HPLC method reported by Çelebier et al. ${ }^{13}$ forced degradation studies were not reported. Some of the methods ${ }^{4,8-12,14}$ were not applied to tablet formulations.

Table 5. Comparison between proposed and reported methods

\begin{tabular}{lccccc}
\hline \multicolumn{1}{c}{ Method } & $\begin{array}{c}\text { Linearity } \\
\mu \mathrm{g} / \mathrm{mL}\end{array}$ & $\begin{array}{c}\text { RSD } \\
\%\end{array}$ & $\begin{array}{c}\text { LOQ } \\
\mu \mathrm{g} / \mathrm{mL}\end{array}$ & $\begin{array}{c}\text { Recovery } \\
\%\end{array}$ & Reference \\
\hline $\begin{array}{l}\text { Visible } \\
\text { spectrophotometry }\end{array}$ & $2-12$ & 0.47 & 0.1 & 98.17 & {$[5]$} \\
$\begin{array}{l}\text { Visible } \\
\text { spectrophotometry }\end{array}$ & $3-21$ & 0.88 & 0.5 & 98.58 & {$[5]$} \\
$\begin{array}{l}\text { Visible } \\
\text { spectrophotometry }\end{array}$ & $30-90$ & 0.94 & 10 & 98.53 & {$[5]$} \\
$\begin{array}{l}\text { Visible } \\
\text { spectrophotometry }\end{array}$ & $5-30$ & 0.52 & 0.5 & 99.30 & {$[5]$} \\
$\begin{array}{l}\text { Visible } \\
\text { spectrophotometry }\end{array}$ & $15-90$ & 1.02 & 5 & 99.25 & {$[5]$} \\
\hline
\end{tabular}




\begin{tabular}{|c|c|c|c|c|c|}
\hline $\begin{array}{l}\text { UV } \\
\text { spectrophotometry }\end{array}$ & $2-12$ & $0.125-0.915$ & 0.298 & 100.85 & [3] \\
\hline $\begin{array}{l}\text { UV } \\
\text { spectrophotometry }\end{array}$ & $2-12$ & $0.205-1.076$ & 0.642 & $99.90-100.50$ & {$[4]$} \\
\hline RP-HPLC & $40-100$ & $0.56-0.66$ & 6 & 98.8 & {$[6]$} \\
\hline RP-HPLC & $50-200$ & 0.471 & 2.47 & 99.708 & [7] \\
\hline $\begin{array}{l}\text { Stability indicating } \\
\text { HPLC }\end{array}$ & $5-40$ & 1.17 & 0.005 & 100.94 & [13] \\
\hline $\begin{array}{l}\text { Stability indicating } \\
\text { HPLC }\end{array}$ & $20-100$ & 0.147 & 0.387 & 100.85 & {$[14]$} \\
\hline HPLC-MS/MS & $0.5-500$ & $7.4^{*}$ & - & $96.3-102.90$ & [8] \\
\hline $\begin{array}{l}\text { Anti-factor Xa } \\
\text { chromogenic assay }\end{array}$ & $0-433.3^{* *}$ & & - & - & [9] \\
\hline $\begin{array}{l}\text { Anti-factor Xa } \\
\text { chromogenic assay }\end{array}$ & - & $7-8.8^{*}$ & - & - & [10] \\
\hline $\begin{array}{l}\text { Anti-factor Xa } \\
\text { chromogenic assay }\end{array}$ & $20-660^{* *}$ & $10-19.1^{*}$ & - & $90-99.09$ & [11] \\
\hline $\begin{array}{l}\text { Anti-factor Xa } \\
\text { chromogenic assay }\end{array}$ & $25-90^{* *}$ & $2.02-5.43^{*}$ & - & - & [12] \\
\hline $\begin{array}{l}\text { Stability indicating } \\
\text { HPLC }\end{array}$ & $1-120$ & $0.064-0.579$ & 0.648 & 99.74 & $\begin{array}{l}\text { Proposed } \\
\text { method }\end{array}$ \\
\hline
\end{tabular}

\section{Conclusion}

A new stability indicating HPLC method was developed and validated for the determination of rivaroxiban. The ICH guideline was adhered for method validation. Satisfactory sensitivity, precision, accuracy, selectivity, specificity and minimum cost are the main features of the developed method. The present study demonstrates the degradation vulnerability of rivaroxiban to different stress conditions. The method was proved adequate for quantitative determination of rivaroxiban in presence of its degradation products. The method was found to be suitable for the analysis of rivaroxiban in tablet dosage form.

\section{Acknowledgement}

One of the authors, BSV Seshamamba, is thankful to the Department of Food Chemistry and Nutrition, College of Food Science and Technology, Bapatla for their continuous support \& encouragement and Rainbow Pharma Training Lab, Hyderabad for providing the necessary facilities to carry out the work.

\section{References}

1. Piccini J P, Patel M R, Mahaffey K W, Fox K A and Califf R M, Expert Opin Investig Drugs, 2008, 17(6), 925-937; DOI:10.1517/13543784.17.6.925

2. Alban S, Curr Pharm Des., 2008, 14(12), 1152-1175.

3. Muralikrishna K S and Kasad P A, Inventi Rapid: Pharm Anal Qual Assur., 2013, Article ID-Inventi:ppaqa/699/13.

4. Sekaran C B, Bind V H, Damayanthi M R and Sireesha A, Der Pharma Chemica., 2013, 5(4), 1-5.

5. Satyanarayana P V V and Madhavi A S, Int J Res Rev Pharma Appl Sci., 2012, 2(4), 611-620. 
6. Satyanarayana P V V and Madhavi AS, Int J Sci Inno Dis., 2012, 2(1), 226-231.

7. Sekhar K C, Vani P S, Lakshmi A D, Devi Ch L L, Anupama B and Narendra D, Research Desk., 2012, 1(1), 24-33.

8. Rohde G, J Chromatogr B Analyt Technol Biomed Life Sci., 2008, 872(1-2), 43-50.

9. Mani H, Rohde G, Stratmann G, Hesse C, Herth N, Schwers S, Perzborn E and Lindhoff-Last E, Thromb Haemost., 2012, 108(1), 191-198.

10. Asmis L M, Alberio L, Angelillo-Scherrer A, Korte W, Mendez A, Reber G, Seifert B, Stricker H, Tsakiris D A and Wuillemin W A, Throm Res., 2012, 129(4), 492-498; DOI:10.1016/j.thromres.2011.06.031

11. Samama M M, Contant G, Spiro T E, Perzborn E, Guinet C, Gourmelin Y, Le Flem L, Rohde G and Martinoli J L, Thromb Haemost., 2012, 107(2), 379-387.

12. Harenberg J, Roland K, Christina G, Svetlana M, Christel W and Martin W, J Thromb Thrombolysis, 2011, 32(3), 267-271; DOI:10.1007/s11239-011-0622-5

13. Celebier M, Recber T, Kocak Engin and Altinoz S, Braz J Pharm Sci., 2013, 49(2), 359-366.

14. Kasad P A and Muralikrishna K S, Asian J Pharm Anal., 2013, 3(2), 62-65.

15. International Conference on Harmonisation of Technical Requirements for Registration of Pharmaceuticals for Human Use Guidelines, Q1A(R2): Stability Testing of New Drug Substances and Products. 2003, 1-24.

16. International Conference on Harmonisation of Technical Requirements for Registration of Pharmaceuticals for Human Use Guidelines, Q2(R1): Validation of Analytical Procedures. 2005, 1-17. 